\title{
Mercury in Hair of Mammoth and Other Prehistorical Mammals as a Proxy of Hg Level in the Environment Associated with Climate Changes
}

\author{
Stella Eyrikh ${ }^{1, * \mathbb{C}}$, Gennady Boeskorov $^{2} \mathbb{D}$, Tatyana Serykh ${ }^{1}$, Marina Shchelchkova ${ }^{3} \mathbb{C}$ \\ and Tatyana Papina ${ }^{1}$ (i) \\ 1 Institute for Water and Environmental Problems, Siberian Branch of the Russian Academy of Science SB RAS, \\ 656038 Barnaul, Russia; tangers62@gmail.com (T.S.); tanya.papina@mail.ru (T.P.) \\ 2 Diamond and Precious Metals Geology Institute, Siberian Branch of the Russian Academy of Science, \\ 677890 Yakutsk, Russia; gboeskorov@mail.ru \\ 3 Biological Department, Institute of Natural Sciences, M.K. Ammosov's North-Eastern Federal University, \\ 677000 Yakutsk, Russia; mar-shchelchkova@yandex.ru \\ * Correspondence: steyrikh@gmail.com; Tel.: +7-385-224-8007
}

Received: 5 October 2020; Accepted: 30 November 2020; Published: 3 December 2020

check for updates

\begin{abstract}
The paper presents the first results of $\mathrm{Hg}$ determination in the hair of prehistorical animals (woolly mammoth, steppe bison, and woolly rhino). Hair of prehistorical mammals can be used as an archive that preserves changes of environmental pollution at the paleoscale. The aim of our study was to assess the levels of $\mathrm{Hg}$ exposure of ancient animals and to understand whether $\mathrm{Hg}$ concentration in hair could be used as a proxy indicating changes of mercury levels in the environment following global climate changes. We assessed changes of $\mathrm{Hg}$ exposure recorded in hairs of seven specimens of mammoth fauna mammals that inhabited the Yakutia region in the period from 45 to $10 \mathrm{ka}$ yr $\mathrm{BP}$. $\mathrm{Hg}$ concentrations in hair varied from 0.017 to $0.177 \mu \mathrm{g} / \mathrm{g}$; the lowest $\mathrm{Hg}$ concentration were determined in older specimens (45-33 kyr yr BP). The two highest concentrations belonged sample from the Last Glacial Maximum and the Karginian interstadial (57-24 kyr BP) periods. Our hypothesis is the increase of $\mathrm{Hg}$ concentrations in hair reflecting environmental $\mathrm{Hg}$ level might be forced by high dust load in cold periods and thawing permafrost in warm climatic periods. Long-term variations of $\mathrm{Hg}$ level recovered from Ice Age animals' hair correlate with $\mathrm{Hg}$ profiles of concentration and deposition reconstructed from the Antarctica ice core.
\end{abstract}

Keywords: mercury; mammoth fauna mammals; hair; environmental changes; paleoclimate; Pleistocene; Yakutia

\section{Introduction}

The content of macro- and microelements in human and animal hairs is a good indicator of their accumulation in the body as a result of environmental exposure, including intake with food and water [1,2]. Hair records the levels of toxic (lead, cadmium, arsenic, etc.) and vital elements (zinc, selenium, iron, etc.), reflecting the elemental status of the whole organism. Hair analysis is used for evaluation of health state, metabolic disorders, mineral maintenance of human and animals, and also the ecological state of the territory where they live [3-5]. The level of toxic metals in the environment indicates a potential risk for the ecosystem and for human and animal health because of bioaccumulation of some metals (particularly mercury) in the body [6,7]. The World Health Organization (WHO) recommends using hair as major biological material for testing the pollution of the human body by heavy metals, since sampling, storage, and analysis of hair samples are easier than they are for other biological materials [8]. The International Atomic Energy Agency (IAEA) uses 
hair for the monitoring of global changes in element levels in the environment worldwide [9-11]. Ancient hairs are also "keepers of history" [12-14] which help to assess the level of environmental pollution by the degree of pollutants impact on the body during previous epochs. Hairs of prehistoric animals can be the key to understanding the relationship of environmental changes with climate. The aim of our study was to understand whether $\mathrm{Hg}$ concentration in the hair of prehistoric mammals could be used as a proxy indicating that changes of mercury level in the environment reflect climate changes during the Late Pleistocene-Early Holocene. Permafrost and substantial precipitation are the deciding factors in preservation of mammoth soft tissues and hair over tens of thousands of years. Hairs of the woolly mammoth are studied very actively nowadays for decoding and sequencing DNA [15-17]; revealing biologic rhythms [18]; determining the type of nutrition from the balance of stable isotopes of nitrogen, carbon, and phosphorus [19,20]; and their response to short-term (seasonal) environmental changes [21]. It is therefore surprising that studies of trace elements in the hair of mammoth fauna mammals have not been done until now. There are some studies of trace element in museum samples of animal hair [22] and bird feathers [23,24], and seal hairs from a lake sediment core spanning the past 2000 years [25]. The results of these studies are useful for assessing environmental changes and anthropogenic impacts on the environment. However, most of the studies cover the span of the last thousand years, whereas the analysis of mammoth fauna mammals' hair provides a unique opportunity to evaluate environmental changes that were happening tens of thousands of years ago, during different climatic stages. It should be noted that there is a potential problem with reliability of analytical data associated with possible contamination or loss of elements during storage and analysis of samples [26]. Therefore, the development of methodological details of sample preparation and analysis of the prehistoric animals' hair require a special attention.

\section{Materials and Methods}

\subsection{Study Sites}

All the studied fossil mammals were discovered on the territory of Yakutia (Eastern Siberia, Russia) (Figure 1).

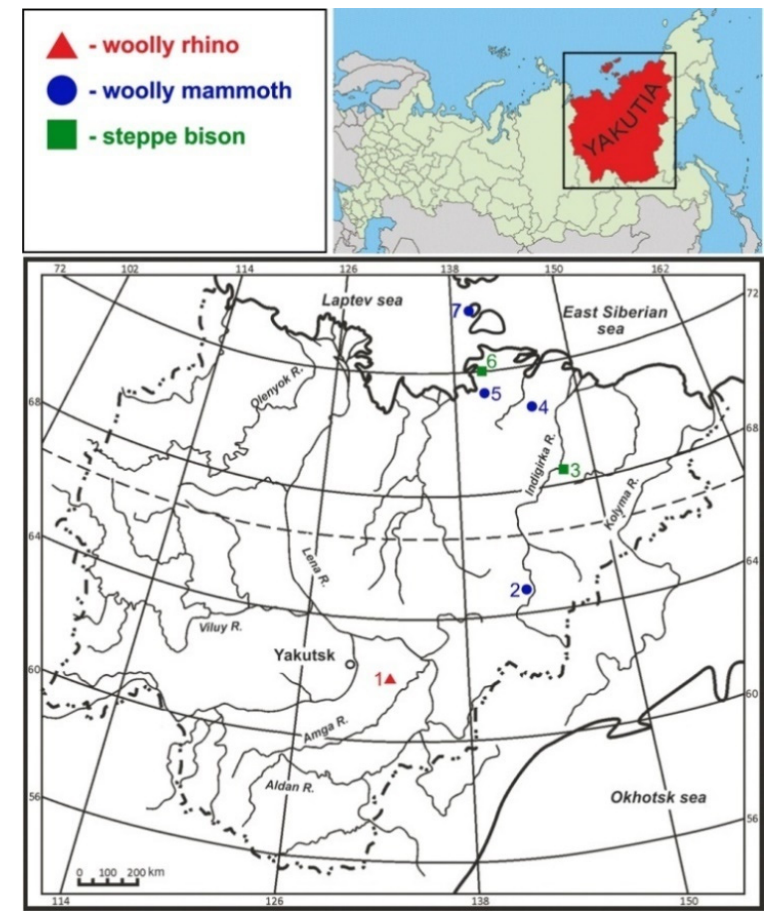

Figure 1. Study area map with location of fossil mammals discovered. Study sites were numbered from south to north. 
For thousands of years, special climatic and geological conditions prevailed in the territory of Yakutia, the harshest climate in Eurasia: long cold season; low-temperatures anaerobic swamps and floodplains of rivers and lakes; gradual accumulation of precipitation on the floodplains; and permafrost growth $[27,28]$. These conditions allowed for the preservation of unique ancient specimens of mammals in permafrost deposits.

We studied seven specimens of Ice Age mammals; their detailed description (location and time of the discovery, estimation of the geological age by radiocarbon dating, sex, and physiological age of the animal) is presented in Table 1 . The calibration of radiocarbon data was carried out by using the IntCal20 calibration curve, the version of program OxCal 4.4 (https://c14.arch.ox.ac.uk/oxcal/OxCal.html).

Table 1. Description of the studied Ice Age mammals.

\begin{tabular}{|c|c|c|c|c|c|c|c|}
\hline \multirow{2}{*}{$\begin{array}{c}\text { Species } \\
\begin{array}{c}\text { Specimen of } \\
\text { the fossil }\end{array}\end{array}$} & \multicolumn{4}{|c|}{ Woolly Mammoth } & \multirow{2}{*}{$\begin{array}{c}\text { Woolly Rhino } \\
\begin{array}{c}\text { Churapcha } \\
\text { rhino }\end{array}\end{array}$} & \multicolumn{2}{|c|}{ Steppe Bison } \\
\hline & $\begin{array}{l}\text { Berelyekh } \\
\text { mammoth }\end{array}$ & $\begin{array}{l}\text { Yukagir } \\
\text { mammoth }\end{array}$ & $\begin{array}{l}\text { Oymyakonsky } \\
\text { baby }\end{array}$ & $\begin{array}{l}\text { Malolyakhovsky } \\
\text { mammoth }\end{array}$ & & $\begin{array}{l}\text { Yukagir } \\
\text { bison }\end{array}$ & $\begin{array}{l}\text { Mylakhchin } \\
\text { bison }\end{array}$ \\
\hline $\begin{array}{l}\text { Number on the } \\
\text { map (Figure } 1 \text { ) }\end{array}$ & 4 & 5 & 2 & 7 & 1 & 6 & 3 \\
\hline $\begin{array}{l}\text { Site and year } \\
\text { of recovery }\end{array}$ & $\begin{array}{c}\text { Berelyekh } \\
\text { Mammoth } \\
\text { Cemetery, } \\
1970\end{array}$ & $\begin{array}{c}\text { Near } \\
\text { Yukagir } \\
\text { settlement, } \\
\text { Ust'-Yanskiy } \\
\text { district, } \\
2003\end{array}$ & $\begin{array}{l}\text { Ol'chan river, } \\
\text { Oimyakonskiy } \\
\text { district, } \\
2004\end{array}$ & $\begin{array}{l}\text { The Malyi } \\
\text { Lyakhovskiy } \\
\text { Island, } \\
2013\end{array}$ & $\begin{array}{c}\text { Lena-Aldan } \\
\text { interfluve, } \\
\text { Churapcha } \\
\text { settlement, } \\
1972\end{array}$ & $\begin{array}{l}\text { Chukchalakh } \\
\text { lake bank, } \\
\text { Ust'-Yansky } \\
\text { district, } \\
2011\end{array}$ & $\begin{array}{c}\text { Indigirka } \\
\text { River, } \\
\text { Mylakhchin } \\
\text { locality, } \\
1971\end{array}$ \\
\hline${ }^{14} \mathrm{C}$ yr BP & $\begin{array}{l}13,700 \pm 80 \\
(\mathrm{MAG}-114)\end{array}$ & $\begin{array}{l}18,510 \pm 80 \\
(\mathrm{GrN}-28258) \\
18,680 \pm 100 \\
(\mathrm{GrN}-24288)\end{array}$ & $\begin{array}{l}41,300 \pm 900 \\
(\mathrm{GrA}-30727)\end{array}$ & $\begin{array}{l}28,660 \pm 160 \\
(\mathrm{GrA}-60021) \\
28,570 \pm 150 \\
(\mathrm{GrA}-60021)\end{array}$ & $\begin{array}{c}19,500 \pm 120 \\
(\text { GIN-9594) }\end{array}$ & $\begin{array}{c}9295 \pm 45 \\
(\mathrm{GrA}-53292)\end{array}$ & $\begin{array}{c}29,560 \pm 100 \\
(\mathrm{SOAN}-1007)\end{array}$ \\
\hline $\begin{array}{c}\text { Cal yr BP, range, } \\
\text { probability }\end{array}$ & $\begin{array}{c}16,901- \\
16,321 \\
(89.1 \%)\end{array}$ & $\begin{array}{c}22,907- \\
22,307 \\
(95.4 \%)\end{array}$ & $\begin{array}{c}45,735-42,904 \\
(95.4 \%)\end{array}$ & $\begin{array}{c}33,655-32,065 \\
(95.4 \%)\end{array}$ & $\begin{array}{c}23,792- \\
23,151 \\
(95.4 \%)\end{array}$ & $\begin{array}{c}10,588- \\
10,336 \\
(95.4 \%)\end{array}$ & $\begin{array}{c}34,398- \\
33,878 \\
(95.4 \%)\end{array}$ \\
\hline $\begin{array}{l}\text { Gender, } \\
\text { age }\end{array}$ & $\begin{array}{c}\text { adult } \\
\text { female }\end{array}$ & $\begin{array}{c}\text { adult male, } \\
45-50 \\
\text { years }\end{array}$ & $\begin{array}{l}\text { baby female, } \\
14-16 \text { month }\end{array}$ & $\begin{array}{l}\text { adult female, } \\
55 \text { years }\end{array}$ & $\begin{array}{l}\text { adult female, } \\
30 \text { years }\end{array}$ & $\begin{array}{c}\text { adult young } \\
\text { male, } \\
4.1-4.5 \text { years }\end{array}$ & $\begin{array}{c}\text { young female, } \\
2.5 \text { years }\end{array}$ \\
\hline $\begin{array}{l}\text { Climatic stage * } \\
\text { Siberian/European }\end{array}$ & LG & LGM & $\begin{array}{l}\text { KARG/ } \\
\text { HAS }\end{array}$ & $\begin{array}{l}\text { KARG/ } \\
\text { DEN }\end{array}$ & LGM & $\begin{array}{c}\text { Preboreal } \\
\text { warming } \\
(\mathrm{PBO})\end{array}$ & $\begin{array}{l}\text { KARG/ } \\
\text { DEN }\end{array}$ \\
\hline Reference & [29] & [30] & [31] & [32] & [33] & [34] & [35] \\
\hline
\end{tabular}

* Climatic stages are explained in Section 2.2. LG, Late Glacial; LGM, Last Glacial Maximum; KARG, Karginian interstadial; HAS, Hasselo stadial; DEN, Denekamp interstadial.

\subsection{Features of Discovered Species and Individuals}

The woolly mammoth (Mammuthus primigenius) is an extinct species that lived during the Pleistocene, until its extinction in the early Holocene epoch. Woolly mammoths lived in open grassland biomes, the mammoth steppe. High-productivity grasses, herbs, and shrubs dominated there. Stomach contents clearly show that the diet of the woolly mammoth was mainly grasses and sedges [36], although tree bark and twigs also constituted a small part of their winter diet [37,38]. Yukagir mammoth (Figure 2a) is an old male who lived during the Last Glacial Maximum (LGM), the maximum Sartanian glaciations in Siberia. He died by falling into a hole. Malolyakhovsky mammoth is an old female discovered on the Maly Lyakhovsky Island (New Siberian Islands in the Laptev Sea). Radiocarbon dating of bones and hairs demonstrated good agreement, attributing the lifetime of the mammoth to the Karginian interstadial (KARG). It was a relatively warm climatic phase in Late Pleistocene in Siberia (57-24 kyr BP), which overlaps with the Denekamp interstadial warming in Europe. Berelyokh mammoth was found in one of the biggest fossil sites, the Berelyokh Mammoth Cemetery located in the basin of the Indigirka River. The entire back leg, $175 \mathrm{~cm}$ long, was discovered (Figure 2c), with the longest hairs reaching $120 \mathrm{~cm}$. Probably it belongs to the adult female which lived in the Late Glacial (LG). Oymyakon mammoth is a baby female; she died by falling into a permafrost crack. Only the upper part of her body is preserved well. This is the oldest of the samples 
from the beginning of the Karginian interstadial in Siberia (Hasselo stadial in European classification). Stocky limbs and thick wool of the woolly rhino (Coelodonta antiquitatis) are well suited to the cold and arid steppe-tundra environment prevalent during the Pleistocene glaciations. "Churapcha rhino" (Figure 2d) is an adult female who lived during the Last Glacial Maximum (LGM); she died by falling into a coastal swamp shortly before it froze.

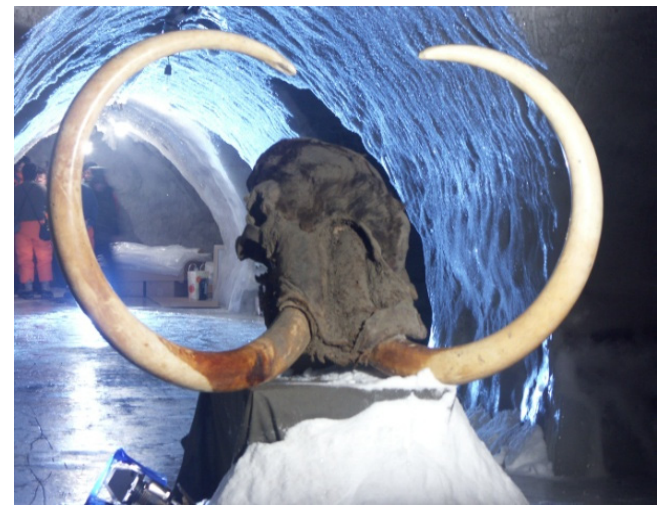

(a)

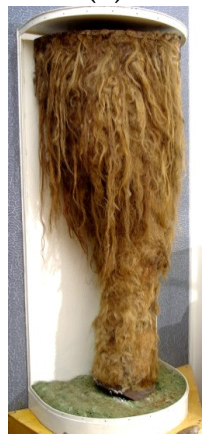

(c)

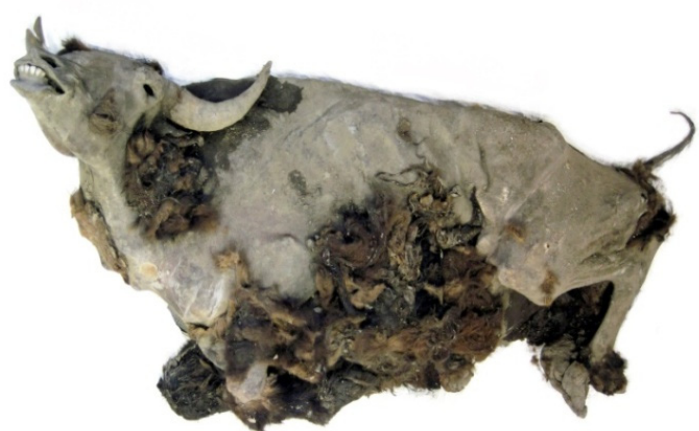

(b)

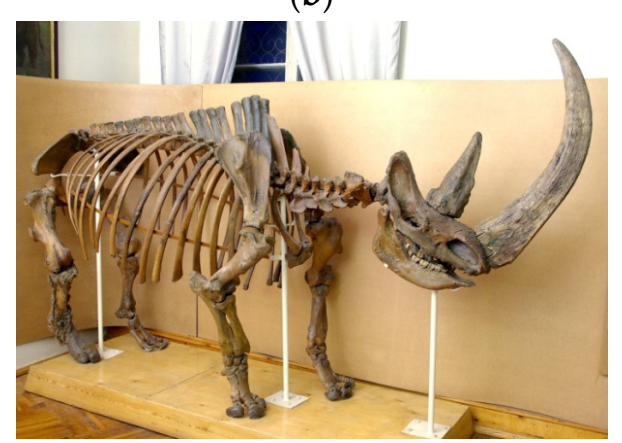

(d)

Figure 2. Photographs of the studied fossils of mammoth fauna mammals: (a) Yukagir mammoth head, (b) Yukagir bison, (c) posterior leg of Berelyokh mammoth, and (d) Churapcha rhino skeleton.

The steppe bison (Bison priscus), the mammoth, and the woolly rhino were the last largest herbivores that survived in Eurasia by the turn of the Pleistocene and Holocene. Steppe bison ate sedges, cereals, and plants from the forbs group. Fossil bison mummies are extremely rare. Only four well-preserved corpses are known, with two of them having been discovered in Yakutia: Yukagir and Malykhchin bison. The Yukagir bison (Figure $2 b$ ) is a young male, a complete frozen mummy that was the youngest of the studied fossil belonging to early Holocene, confirming that the bison survived an abrupt climate change at the Pleistocene-Holocene Boundary. The Malykhchin bison is a young female found on the right bank of the Indigirka River, where she died by getting stuck in coastal mud in the summer. She ate forest herbs, branches, and foliage. The presence of mosses in her stomach indicates the existence of wetland biotopes during the life of bison in the warm period of the Karginian interstadial.

Isotopic biogeochemistry helps to reveal the ecological structure of the mammoth steppe fauna. Isotopic differences reflect different dietary choices by herbivores. Woolly rhinoceros and bison grazed fresh grass, and mammoths consumed dry grass. Despite some differences in nitrogen and carbon isotopes, woolly mammoths and woolly rhinoceros are considered globally similar in diet (grass) and physiology (monogastric) [19]. Thus, it can be assumed that the differences in the concentration of mercury between the hairs of different animals reflect the changes in concentration of $\mathrm{Hg}$ in the environment. 
Hair samples of woolly mammoth, woolly rhino, and steppe bison were obtained from the Geological Museum of Diamond and Precious Metals Geology Institute (Yakutsk). Hair records the cumulative exposure to mercury in the short- to medium-term, depending on the length of the hair sample. Whereas human hair growth rate is about $1 \mathrm{~cm}$ per month, and the concentration of metal in hair can show the level of mercury exposure that has occurred over many years, the animal's hair is replaced every 1-1.5 year (it holds for most of animals, both ancient and modern). Therefore, the full length of hair represents a continuous record of the elements intake over this period. Mammoth hair grows approximately $31 \mathrm{~cm} /$ year; the longest hair ever found covers 39 month of a mammoth's life [18,21]. Thus, the hair of mammoths and other mammoth fauna mammals reflects the environmental situation in the last years of their lives.

\subsection{Sample Preparation}

The determination of mercury in the hair of prehistoric animals and museum exhibits is associated with a number of difficulties: obtaining a representative sample, choosing an appropriate method given the small amount of sample, and reliable analytical determination of $\mathrm{Hg}$ concentration in it. Loss of volatile $\mathrm{Hg}$ and sample contamination are possible during long-term storage and transportation of the sample. Samples of studied fossil animals' hair were stored in museum in glass cases or wooden boxes in conditions excluding their mercury contamination during storage and therefore, they are suitable for analysis.

The amount of prehistoric animals' hair is very limited, and a single procedure of sample preparation must be developed not only for $\mathrm{Hg}$, but also for a wide range of other trace elements. Here we aimed to determine the total concentrations of mercury in the hair of prehistoric animals both endogenous and exogenous in origin reflecting the intake from food and water, as well as from the air.

Methylmercury easily incorporated into hairs as it grows and its concentration in the hair is proportional to the blood concentration. The high affinity of hair for metals is mainly due to the presence of cysteine or sulfhydryl (SH) groups [39]. Elemental mercury may also bind to the hydrophobic core of the melanin polymer in the hair structure [40]. The IAEA recommends hair washing procedure using acetone and deionized water [10]; it is not suitable for $\mathrm{Hg}$ because the fat and keratin structures of the hair are destroyed by acetone, which leads to the loss of endogenous mercury. Washing the hair with $\mathrm{HCl}$ solution can leach methyl mercury from hair samples [41]. We used a chemically inert detergent ("SYNERGETIC Baby", fragrance and color free) which removes only surface grease and dust from hair samples without disturbing their structure. All reagents were tested for $\mathrm{Hg}$ content and purified if necessary. Nitric and hydrochloric acids were purified using a Savillex DST-1000 distillation system (Savillex, Eden Prairie, MN, USA). Ultrapure water (MQ-water) was obtained using a Simplicity UV water purification system (Millipore SAS, Molsheim, France). All stages of sample preparation were carried out in a "clean room" equipped with outdoor air handlers that use progressively finer filters including high-efficiency particulate air (HEPA) filter and charcoal mercury filter, which remove particulate and elemental mercury from the incoming air.

The washing procedure for hair comprises the following steps:

(1) Washing the samples in a solution of chemically inert detergent (30 min);

(2) Three-fold soaking in MQ-water (during the day);

(3) Air-drying in a clean room;

(4) Cutting hair into small pieces of less than $0.3 \mathrm{~cm}$ (scissors pretreated with detergent and ultrapure water);

(5) Careful homogenization of the obtained samples by mixing to provide a representative sub-sampling;

(6) Storage in a double-sealed zipper-locked plastic bag, in a clean room.

Microwave system MARS-5 (Thermo Fisher Scientific, Waltham, MA, USA) was used for digestion of hair samples by the program previously optimized for $\mathrm{Hg}$ analysis in biological objects (Table 2) [42]. 
We tested acid and acid-peroxide digestion and demonstrated applicability of acid-peroxide digestion $\left(2 \mathrm{~mL} \mathrm{HNO}_{3}+1 \mathrm{~mL} \mathrm{H}_{2} \mathrm{O}_{2}\right.$ ) for $\mathrm{Hg}$ analysis. The latter method was used for the analysis of samples.

Table 2. Optimized parameters of microwave digestion of biotic samples.

\begin{tabular}{|c|c|c|c|c|c|}
\hline Stage & Power, W/\% & Time, min & Pressure, psi & Temperature, ${ }^{\circ} \mathrm{C}$ & Retention Time, min \\
\hline 1 & $1200 / 100$ & 5 & 20 & 85 & 5 \\
\hline 2 & $1200 / 100$ & 5 & 80 & 140 & 0 \\
\hline 3 & $1200 / 100$ & 5 & 160 & 180 & 0 \\
\hline 4 & $1200 / 100$ & 5 & 190 & 180 & 10 \\
\hline
\end{tabular}

After microwave digestion the samples were cooled to $25^{\circ} \mathrm{C}$, the pressure was brought to $<50 \mathrm{psi}$, and sample volume was adjusted to $10-12 \mathrm{~mL}$ with $\mathrm{MQ}$ water. The procedure of sample preparation (washing, cutting, and digestion) was developed and tested by using hair samples of modern yak living in the Barnaul Zoo and Certified Reference Material of human hair (CRM, Hair NSC DC 73347, China). The developed sample-preparation procedure is suitable for both for $\mathrm{Hg}$ and multi-element analysis of prehistorical animals' hair and blood.

\subsection{Hg Analysis}

Content of mercury in hair and blood samples was determined by Mercur Duo Plus Analyzer (Analytik Jena, Jena, Germany), combining atomic fluorescence with the cold vapor method and amalgamation on gold collector. Analytical characteristics of the method are presented in Table 3. The accuracy was confirmed by using Certified Reference Material of human hair (CRM, Hair DC 73347, China). Optimization of the instrumental parameters [43], using ultrapure reagents and clean conditions, allowed us to achieve a method detection limit of up to $0.4 \mathrm{ng} / \mathrm{L}$ for liquid samples and $0.003 \mu \mathrm{g} / \mathrm{g}$ for hair samples ( $0.03 \mathrm{~g}$, dry weight). Split sampling and analyzing the same samples at different times and by different operators were used for assessing precision, recovery, and reproducibility. Good spike recovery values were demonstrated for samples of yak hair and CRM. The confidence interval for low-concentration samples did not exceed $17 \%$.

Table 3. Analytical characteristics of method.

\begin{tabular}{|c|c|c|c|c|c|c|c|}
\hline \multirow{2}{*}{ Element } & \multicolumn{2}{|c|}{ Accuracy, $\mu \mathrm{g} / \mathrm{g}$} & \multicolumn{2}{|c|}{ Spike Recovery, \% } & \multicolumn{2}{|c|}{ Precision $(\%)$} & \multirow{2}{*}{$\begin{array}{l}\text { Method Detection } \\
\text { Limit, } \mu \mathrm{g} / \mathrm{g}\end{array}$} \\
\hline & Measured Value & Certified Value $^{1}$ & CRM & Yak & Within Run & Between Runs & \\
\hline $\mathrm{Hg}$ & $0.36 \pm 0.04$ & $0.36 \pm 0.08$ & 94.7 & 100.4 & $3 \%$ & $5 \%$ & 0.003 \\
\hline
\end{tabular}

\section{Results and Discussion}

\subsection{Hg Concentration in Fossil Animals' Hair}

Mercury concentrations determined in the prehistoric animals' hair varied from 0.017 to $0.177 \mu \mathrm{g} / \mathrm{g}$; average concentrations and ranges of $\mathrm{Hg}$ content in different types of prehistoric and modern animals are presented in Table 4, together with reference values and intervals. Mercury coming directly from water, air, and food tends to accumulate in both plants and animals, being toxic to most life forms. WHO guidance established $2 \mu \mathrm{g} / \mathrm{g}$ for total $\mathrm{Hg}$ in human hair as the reference level for risk evaluation [44]. The US Environmental Protection Agency (EPA) sets the reference dose for human hair and wildlife toxicity at $1 \mu \mathrm{g} / \mathrm{g}$ [45]. All of the prehistoric animals' hairs have $\mathrm{Hg}$ concentrations significantly below these levels. Moreover, they do not exceed the background level of mercury in hair of non-seafood consumers $(0.5 \mu \mathrm{g} / \mathrm{g})$. As far as we are aware, there is no background assessment of $\mathrm{Hg}$ level in herbivore prehistorical animals. We can compare our results with $\mathrm{Hg}$ concentrations in the hair of modern herbivore animals and their reference intervals for $\mathrm{Hg}$ (discussed in Section 3.2). 
Table 4. Hg concentrations in hair of modern and prehistoric animals and reference values.

\begin{tabular}{|c|c|c|c|c|c|c|}
\hline \multirow{2}{*}{$\mathrm{Hg}$ Concentration, $\mu \mathrm{g} / \mathrm{g}$} & \multicolumn{3}{|c|}{ Prehistoric Animals } & \multicolumn{2}{|c|}{ Modern Animals } & \multirow{2}{*}{ Reference Values } \\
\hline & Mammoth & Bison & Woolly Rhinoceros & Yak & Cattle & \\
\hline number of samples & 4 & 2 & 1 & 1 & 145 & - \\
\hline hair average & 0.031 & 0.11 & 0.092 & 0.0056 & $0.0066[46]$ & $\begin{array}{c}1[45] \\
<0.5[47]\end{array}$ \\
\hline hair range & $0.017-0.049$ & $0.035-0.177$ & - & - & $0.002-0.011[48]$ & $0.02-0.042[48]$ \\
\hline blood* & $0.69 \pm 0.07$ & - & - & - & $<0.438$ (ND-15.4) [49] & $<2[45]$ \\
\hline
\end{tabular}

\subsubsection{Woolly Mammoth Hair and Hemolyzed Blood}

Hairs of four fossil mammoths were studied; the $\mathrm{Hg}$ concentrations are shown in the Figure 3a. Higher concentrations were in hair samples of Berelyekh and Yukagir mammoths from the Last Glacial and Preboreal warming, respectively, whereas the lowest $\mathrm{Hg}$ concentrations were in older specimens, Oymyakonsky and Malolyakhovsky mammoths (45-33 ka yr BP).

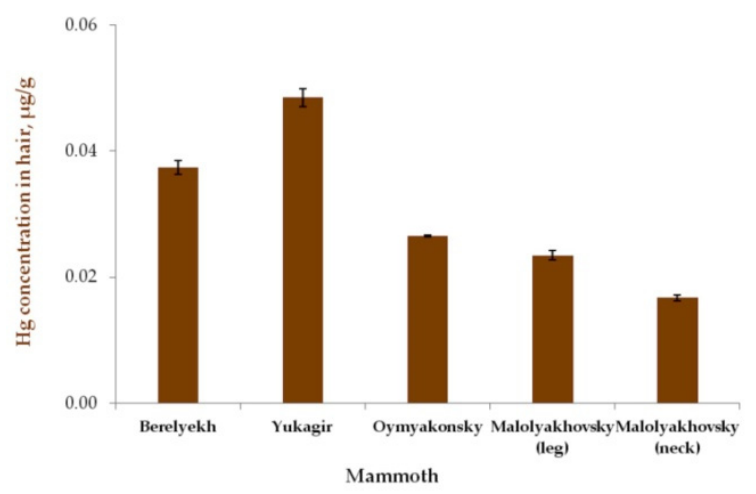

(a)

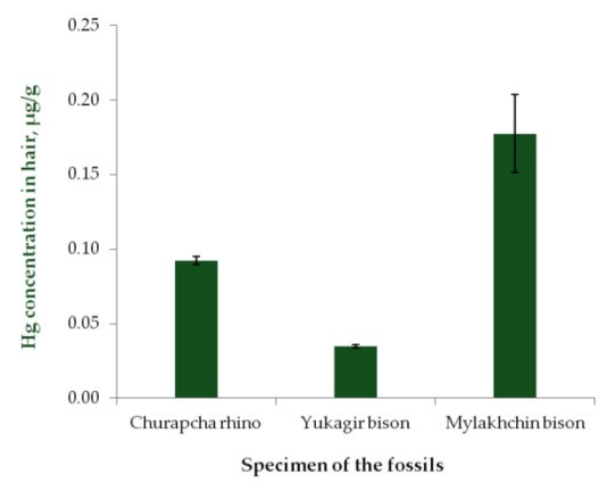

(b)

Figure 3. Mercury concentration in hair of different fossil specimens: (a) mammoth; (b) bison and rhino.

There was rare opportunity to sample enough freshly thawed hair material from different parts of the body of the same animal (Malolyakhovsky mammoth). Samples of hair taken from the neck and back leg demonstrated slightly different concentrations: 0.017 and $0.024 \mu \mathrm{g} / \mathrm{g}$, respectively. The difference between $\mathrm{Hg}$ concentrations sampled from different body areas for modern animals varied insignificantly for yak from 0.004 to $0.007 \mu \mathrm{g} / \mathrm{g}$ (this study) and for beef cattle from 0.062 to $0.070 \mu \mathrm{g} / \mathrm{g}$ [46]. The comparison of guard and down yak hair demonstrated a negligible difference in $\mathrm{Hg}$ concentrations: 0.0054 and $0.0058 \mu \mathrm{g} / \mathrm{g}$, respectively. Cattle hair also yielded similar $\mathrm{Hg}$ concentrations: 0.010 and $0.008 \mu \mathrm{g} / \mathrm{g}$ for guard and down hairs. It was shown that the elemental composition and concentrations of most elements of beef cattle hair on different body areas does not differ notably [46]. Of course, in the ideal case, hair sampled from the same body areas should be used for the comparison of the animals. However, unfortunately, there are very few opportunities to get hair samples from the same part of body for different prehistoric animals. Therefore, comparison of prehistoric animals' hair sampled from different body surface areas is evidently acceptable due to minor differences in the concentrations as confirmed by our results (no more than $30 \%$ ).

There was rare chance to determine $\mathrm{Hg}$ concentration in hemolyzed blood of Malolyakhovsky mammoth. Mercury measurement in the whole blood provides information about recent exposure ( 1-2 months) to both organic and inorganic mercury through ingestion of food and drinking water and inhalation of elemental mercury vapor in ambient air. The level of mercury in blood indicates recent exposure, but it does not reflect historical exposure or variations in exposure. Here we determined $\mathrm{Hg}$ concentration in mammoth hemolyzed blood $0.69 \pm 0.07 \mu \mathrm{g} / \mathrm{L}$. Hg levels in mammoth blood are below background levels of mercury in the blood of people who do not consume fish 
$(<2 \mu \mathrm{g} / \mathrm{L})$ [45]. It is comparable with relatively low levels of total mercury in the blood of modern animals: The median value of $\mathrm{Hg}$ in blood of Galician cows from NW Spain was $<0.438 \mu \mathrm{g} / \mathrm{L}$, with the range of $<0.438$ to $15.4 \mu \mathrm{g} / \mathrm{L}$ [49]. This is similar to $\mathrm{Hg}$ concentrations in blood of surveyed dogs from Alaska (0.16-12.38 ng/g) [50].

Hair to blood $\mathrm{Hg}$ ratio in Malolyakhovsky mammoth was 36, which is closer to the hair to blood ratio in fish-fed dogs (59 \pm 7.6$)$, harbor seals (22-40), and polar bears (100) [51], than to the WHO value for humans (250) used for risk assessments to predict blood $\mathrm{Hg}$ from hair concentrations [8]. The differences in ratios may be due to the differences in relative surface area and hair density for different animal species and humans. Unfortunately, we have a single blood sample for mammoth, so we can only assume that this ratio level is characteristic for mammoths and other Ice Age animals.

\subsubsection{Steppe Bison Hair}

$\mathrm{Hg}$ concentrations in the hair of two steppe bison differ by about five times: $0.035 \pm 0.001$ and $0.177 \pm 0.026 \mu \mathrm{g} / \mathrm{g}$ (Figure 3b). The concentration of $\mathrm{Hg}$ in Yukagir bison hair is at a comparable level to the Berelekh mammoth hair, whereas Hg concentration in hair of Mylakhchin bison is the highest among all studied Ice Age animals. We hypothesize that there was an increase in mercury concentrations in the environment during this period. Mylakhchin bison lived in Karginian interstadial, in conditions of climate warming. The latter might be responsible for enhanced release of $\mathrm{Hg}$ due to thawing permafrost. Reconstruction based on palynological data revealed that, during the Karginian interstadial, there were stages with warmer and milder-than-today climate conditions, and the amplitude of climate fluctuations was different for different regions of Siberia [52]. Modern bison are very similar to the prehistoric ones in terms of nutrition, wool structure, etc. It has been observed that bison can find food under deep snow layers $(>50 \mathrm{~cm}$ ) [53]. Unfortunately, we could not find mercury concentrations in the hair of modern bison, although very low levels of hepatic $\mathrm{Hg}$ in the liver of captive and free-ranging European Bison from two different sites $(0.003 \mu \mathrm{g} / \mathrm{g})$ indicate a low mercury load [54]. The levels of such vital trace elements, such as iron, titanium, and vanadium, in the hair of a modern European bison are much lower than in hair of both prehistoric fossils [55].

\subsubsection{Woolly Rhino Hair}

There was only one sample of woolly rhino hair, and it had a high $\mathrm{Hg}$ concentration of $0.092 \pm 0.003 \mu \mathrm{g} / \mathrm{g}$ (second highest of all studied samples). This is supposedly related to $\mathrm{Hg}$ variability based on climatic stage and is discussed in detail in Section 3.4.

\subsection{Comparison with Modern Animals' Hair and Reference Intervals}

Unfortunately, we cannot compare Hg levels in modern animals to historical levels in the same animal species, because there are no modern animals identical to the mammoth mammals. Elephants are closest to mammoths genetically, but they have a different body and habitat. We compared the $\mathrm{Hg}$ concentration in hair of mammoth and yak, as they have similar characteristics (nutrition, long hair, etc.). A yak (Bos mutus) from the Barnaul Zoo has a low Hg level $(0.006 \pm 0.001 \mu \mathrm{g} / \mathrm{g})$ (Table 4). There are no data about $\mathrm{Hg}$ concentration in the hair of yak from other regions of the world, but concentrations of other elements were found to be comparable between Altai and Asian yak, indicating that the differences in their exposure to metals are insignificant for the vast territories of their habitats [56,57]. $\mathrm{Hg}$ concentrations in all mammoth mammals' hair samples were significantly higher than $\mathrm{Hg}$ concentration in unpolluted hair samples of modern animals such as cattle $(0.0066 \pm 0.0002 \mu \mathrm{g} / \mathrm{g})$ (Table 4). Methods for determining reference ranges in hair by using results from a large human population are described in detail elsewhere [11]. The reference intervals and $90 \%$ confidence intervals for the lower and upper limits were calculated for hair trace-element content in cattle (Bos taurus) per the recommendations of the American Society for Veterinary Clinical Pathology Quality Assurance and Laboratory Standard Guidelines $[48,58]$. Concentrations of $\mathrm{Hg}$ in mammoth fauna mammals' hair mostly lie within the optimal reference range for cattle (Table 4), excluding two highest concentrations, 
which apparently reflect high environmental exposure to mercury in these mammals during the last periods of their lives. For plant-eating animals, vegetation is one of the main factors characterizing the living conditions [20], although $\mathrm{Hg}$ accumulation by animals depends both on their diet and habitat.

\subsection{Hg Levels in Arctic Animals and Humans (Historical and Modern)}

In historical samples of hair of human mummies of the Aleutian Islands (Alaska) dating $1450 \mathrm{AD}$, mean total mercury concentration $(5.8 \pm 0.9 \mu \mathrm{g} / \mathrm{g})$ is comparable to the levels observed in hair of modern residents of the northern polar territories (Alaska, Canada, Faroe Islands) [59]. That confirms the main contribution of the traditional nutrition based on fish and meat of marine mammals to the accumulation of mercury for residents of these territories. The Egyptian, Chilean, and Peruvian mummies had mercury exposures below the US EPA reference level of $1 \mu \mathrm{g} / \mathrm{g}$ and were considerably lower than that of northern pre-industrial populations [60]. Hg concentrations in hair samples of historical $(10.42 \pm 1.31 \mu \mathrm{g} / \mathrm{g})$ and modern $(10.42 \pm 2.45 \mu \mathrm{g} / \mathrm{g})$ arctic foxes were similar and strongly correlated with ecotype and available food source [22]. Unlike humans and foxes, $\mathrm{Hg}$ concentrations in the hair of Greenland polar bears showed a significant increase from 0.52 to $4.9 \mu \mathrm{g} / \mathrm{g}$ (from 1300 to 2000 years) [61]. Comparison between $\mathrm{Hg}$ levels in the hair of the ancient dogs of the Seward Peninsula $(0.657 \pm 0.273 \mathrm{ng} / \mathrm{g}$ [62] $)$ and the modern Alaska fish-fed dogs $(0.54 \pm 0.11 \mu \mathrm{g} / \mathrm{g}$, [51] $)$ did not show significant difference. Thus, when environmental exposure (atmosphere and water) to mercury is low, the increased levels of mercury in the bodies of ancient humans and animals are primarily associated with their diet. Mammals of the mammoth fauna have low Hg levels, since they are herbivores that get mercury from plants and accumulate it in their bodies (and hair). Biomagnification along the food chain (as seen in aquatic ecosystems and fish-eating animals and humans) is not observed.

\subsection{Comparison with Other Paleoarchive Data}

Environmental archives such as lake and marine sediments, peat bogs, glacial ice, and tree rings are widely used to reconstruct $\mathrm{Hg}$ accumulation at the local, regional, and global scale. All archives have their advantages and disadvantages, but none of them is a definite record of past mercury levels, because of the complexity of the mercury cycle's being influenced by various processes in each archive [63,64]. Most archives record the past several hundred to several thousand years (ice cores, peat bogs, lake and marine sediment cores, and tree rings), whereas long-term paleorecords recording up to a hundred thousand years are scarce (ice cores of Antarctica and Greenland, sediments cores and speleothems). Ice Age animals in this study lived 45 up to $10.5 \mathrm{kyr} \mathrm{BP}$. Animals were exposed to mercury from the diet and the environment. The natural sources of $\mathrm{Hg}$ emissions were volcanoes, air-sea and soil-vegetation-air exchange, biomass burning (wildfires), and the revolatilization of deposited $\mathrm{Hg}$ from the soils (including release associated with permafrost thawing due to climate change).

The highest $\mathrm{Hg}$ concentration recorded in this study dates to $33.930 \mathrm{cal} \mathrm{kyr}$ BP. The other peak of $\mathrm{Hg}$ concentration at $23.292 \mathrm{cal} \mathrm{kyr}$ BP falls into the LGM period. An increase of mercury concentrations in hair coincides with variations of $\mathrm{Hg}$ concentrations and depositions recorded in the Antarctica Dome $\mathrm{C}$ ice core (Figure 4). Due to constant snow accumulation, $\mathrm{Hg}$ concentrations and fluxes change synchronically. Total $\mathrm{Hg}$ and $\mathrm{Hg}^{2+}$ concentrations are also characterized by similar trends, except during the initial period from 15 to $2 \mathrm{kyr}$ BP. The highest peak occurred during the Karginian interstadial of the Late Pleistocene, the period of maximum insolation in 200 ka years [65]. The presence of mosses in Malykhchinsky bison's food masses indirectly indicated a significant wetland area in this period because of significant climate warming. Hg increase in environment caused by rapid release of mercury during thawing periods was recorded in other paleoarchives, such as sediments in Limnopolar Lake (South Shetland Islands), where extraordinary high Hg enrichment was observed [65]. Research based on about 600 samples from soil permafrost cores (Alaska) discovered that the active layer is the largest $\mathrm{Hg}$ pool on the planet. The Northern Hemisphere permafrost region contains $1656 \pm 962 \mathrm{Gg} \mathrm{Hg}$, of which $793 \pm 461 \mathrm{Gg}$ is frozen in permafrost. The active layer and permafrost contain nearly twice as much $\mathrm{Hg}$ as all other soils, the ocean, and the atmosphere combined [66]. 
This allows us to assume that, in the past warm climatic periods, thawing permafrost caused significant mercury to be released into the environment, from the active layer of permafrost.

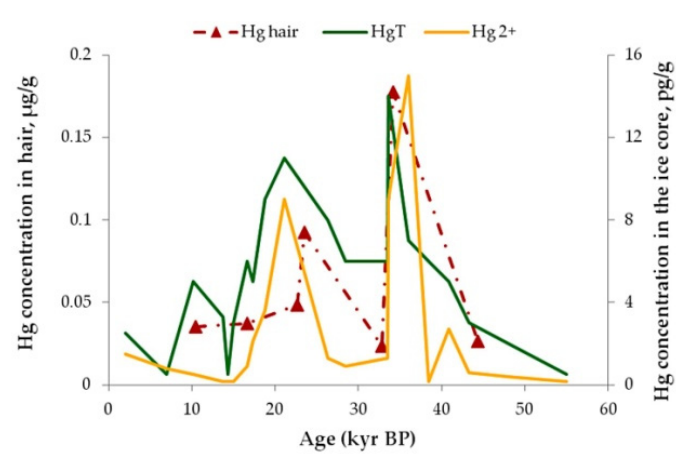

(a)

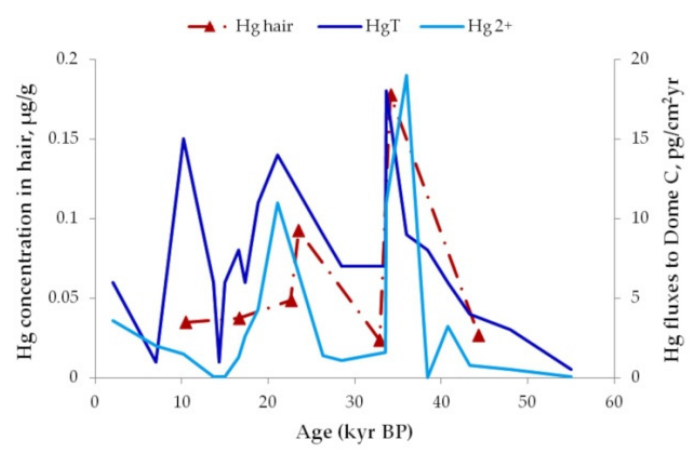

(b)

Figure 4. Concentrations (a) and fluxes (b) of total mercury (HgT) and inorganic mercury $\left(\mathrm{Hg}^{2+}\right)$ in the EPICA Dome $\mathrm{C}$ ice core [67] and total $\mathrm{Hg}$ concentrations in mammoth fauna mammals' hair. Concentrations and fluxes of $\mathrm{Hg}$ below the Method Detection Limit (MDL) are presented in the graph as $1 / 2$ of MDL.

The exogenous $\mathrm{Hg}$ in hair of ancient animals is mainly due to its sorption on the hair surface, from the atmosphere. The endogenous $\mathrm{Hg}$ in hair also can be due to $\mathrm{Hg}^{0}$ influx. Elemental mercury (up to $80 \%$ of inhaled $\mathrm{Hg}^{0}$ vapors) is absorbed in the lungs, quickly diffused into the blood, and distributed to all organs of the body; it also accumulates in growing hair.

The second peak corresponds to the Last Glacial Maximum, where the Antarctic record also shows a drastic increase in $\mathrm{Hg}$ concentrations during the LGM. It was found for mercury in the Antarctic [67] that the oxidation of gaseous mercury by sea-salt-derived halogens occurred in the cold atmosphere. The oxidized mercury compounds were then transferred to the abundant mineral dust particles and deposited. A significant correlation between dust concentrations and changes of temperature during glacial periods was confirmed by comparing dust and stable isotope, up to $90 \%$ of the dust variability can be explained by the temperature variations. The deposition of dust in Antarctica during glacial periods is about 20 times higher than during interglacials [68]. The cooling marked in three independently dated North Atlantic marine sediment cores is synchronous with the sharp increase in dust flux recorded in the Greenland ice cores, an increase in dust transport from Asia to Greenland observed during few Greenland stadials [69,70]. Deposition of mercury with dust on the surface of the land and its accumulation by the plants and snow might be the reason of increased dietary $\mathrm{Hg}$ exposure of herbivores. A high content of loamy particles in fecal samples of mammoths indicates an occasional or deliberate lithophagy [71]. Moreover, when thick ice completely covers the water, animals eat snow. Thus, changes of mercury concentrations in the hair of prehistoric animals are in good agreement with global changes of mercury concentrations recorded in other paleoarchives of Northern Hemisphere. It should be noted that the question remains open: Is there is a real difference in the deposition, distribution, and conservation of mercury in the Northern and Southern Hemispheres, or are $\mathrm{Hg}$ changes global? All archives preserve $\mathrm{Hg}$ differently and present changes in global $\mathrm{Hg}$ cycle at various spatial and temporal scales [64].

\section{Conclusions}

Mercury content in the hair of mammoths and other prehistoric animals allows us to estimate changing mercury levels between 40,000 to 10,000 years ago. Since the amount of ancient hair is very limited, we suggest comparing the hair of different animal species which are similar in diet and habits, as well as hair samples taken from different parts of the animals' body. All prehistoric animals have a low $\mathrm{Hg}$ level in their hair. This level is below concentrations associated with toxicity in wildlife and do 
not exceed background levels of mercury in hair of non-seafood consumers $(0.5 \mu \mathrm{g} / \mathrm{g})$. Most of the $\mathrm{Hg}$ concentrations in the hair of prehistoric animals were within the reference range for modern cattle.

There are many advantages to using ancient hair as an indicator of environmental pollution, and now we present a new application of hair as an indicator of climatic changes. We hypothesize that $\mathrm{Hg}$ concentrations in hair reflect the variation in $\mathrm{Hg}$ level in the environment changing with climate changes, and can be used as a proxy for climate change assessment. The increase of $\mathrm{Hg}$ concentration in hair during the coldest climatic stages (such as LGM) coincides with the increase in Hg deposition on the Earth's surface, associated with the highest atmospheric dust loads. Moreover, mercury can be released to the atmosphere because of permafrost thawing during interstadial warming; the highest $\mathrm{Hg}$ concentration coincides with the Karginian interstadial of the Late Pleistocene, the period of maximum insolation and warming. Climate changes in warm and cold climatic stages were oscillatory; relatively warm periods alternated with cooler periods during each glacial and interglacial. For example, Karginian interstadial consisted of five periods (three warming and two cooling), in which features of the distribution and boundaries of permafrost are still under study.

Mammoth fauna mammals' hair, together with other natural archives, will be useful in assessing the response of $\mathrm{Hg}$ cycle to climate change. More paleo data are necessary to confirm our first finding, and to clarify whether these changes will differ for the Northern and Southern Hemispheres' archives, so we are planning further studies of mammoth fauna mammals on a wide spatiotemporal scale.

Author Contributions: This work was carried out in the framework of cooperation between Institute for Water and Environmental Problems from Barnaul, Diamond and Precious Metals Geology Institute, and Ammosov's North-Eastern Federal University from Yakutsk. Conceptualization and investigation, S.E. and G.B.; mammoth samples and morphological information, G.B.; methodology, S.E.; investigation and analysis, T.S., S.E., and M.S.; supervision T.P.; resources and funding acquisition, G.B. and T.P.; writing-original draft preparation, S.E.; writing-review and editing, S.E., G.B., and T.P. All authors have read and agreed to the published version of the manuscript.

Funding: This research was performed under a State Assignment of the IWEP SB RAS (project no. AAAA-A17117041210242-1). Studies by G.G. Boeskorov were performed under a State Assignment of the Institute of Diamond and Precious Metal Geology, Siberian Branch, Russian Academy of Sciences (project no. 0381-2019-0002); studies by M.V. Shchelchkova were performed under a State Assignment of the Ministry of Education and Science of the Russian Federation (project no. 37.7935.2017/6.7).

Acknowledgments: We are grateful to the Director of the Barnaul Zoo Sergey Pisarev for his help in obtaining yak hair samples for method testing. We expressed our deep gratitude to Eugenia Bakunova for kind help in English editing of the manuscript.

Conflicts of Interest: The authors declare no conflict of interest.

\section{References}

1. Airey, D. Mercury in human hair due to environment and diet: A review. Environ. Health Perspect. 1983, 52, 303-316. [CrossRef] [PubMed]

2. Hejna, M.; Gottardo, D.; Baldi, A.; Dell'Orto, V.; Cheli, F.; Zaninelli, M.; Rossi, L. Review: Nutritional ecology of heavy metals. Animal 2018, 12, 2156-2170. [CrossRef] [PubMed]

3. Combs, D.K.; Goodrich, R.D.; Meiske, J.C. Mineral concentrations in hair as indicators of mineral status-A review. J. Anim. Sci. 1982, 54, 391-398. [CrossRef] [PubMed]

4. Katz, S.A.; Chatt, A. Hair Analysis: Applications in the Biomedical and Environmental Sciences; VCH Publishers: New York, NY, USA, 1988.

5. Jung, R.-S.; Yang, S.-R.; Han, J.K.; Kang, G.H.; Lee, G.H. Determination of Lead, Cadmium, and Chromium in Hair Optimized by Simplex Method Using Electrothermal Vaporization-Inductively Coupled Plasma Mass Spectrometry. Anal. Sci. Suppl. 2002, 17icas, i999-i1002. [CrossRef] 
6. Pavlogeorgatos, G.; Kikilias, V. The importance of mercury determination and speciation to the health of the general population. Glob. Nest Int. J. 2002, 4, 107-125.

7. Okpala, C.O.R.; Sardo, G.; Vitale, S.; Bono, G.; Arukwe, A. Hazardous properties and toxicological update of mercury: From fish food to human health safety perspective. Crit. Rev. Food Sci. Nutr. 2018, 58, 1986-2001. [CrossRef]

8. Human Biomonitoring: Facts and Figures; WHO Regional Office for Europe: Copenhagen, Denmark, 2015.

9. Mercury Contamination in Man and His Environment; International Atomic Energy Agency: Vienna, Austria, 1972.

10. International Atomic Energy Agency, Agency's Laboratories, Analytical Quality Control Services. Activation Analysis of Hair as an Indicator of Contamination of Man by Environmental Trace Element Pollutants; Ryabukhin, Y.S., Ed.; International Atomic Energy Agency (IAEA): Seibersdorf, Austria, 1976; p. 135.

11. Druyan, M.E.; Bass, D.; Puchyr, R.; Urek, K.; Quig, D.; Harmon, E.; Marquardt, W. Determination of reference ranges for elements in human scalp hair. Biol. Trace Elem. Res. 1998, 62, 183-197. [CrossRef]

12. Toribara, T.Y.; Muhs, A.G. Hair: A Keeper of History. Arct. Anthropol. 1984, 21, 99-108.

13. Egeland, G.M.; Ponce, R.; Knecht, R.; Bloom, N.S.; Fair, J.; Middaugh, J.P. Trace metals in ancient hair from the Karluk Archaeological Site, Kodiak, Alaska. Int. J. Circumpolar Health 1999, 58, 52-56.

14. Thompson, A.H.; Wilson, A.S.; Ehleringer, J.R. Hair as a geochemical recorder: Ancient to modern. In Treatise on Geochemistry, 2nd ed.; Turekian, K.K., Holland, H.D., Eds.; 14-Archaeology \& Anthropology; Elsevier: Amsterdam, The Netherlands, 2014; pp. 371-393. [CrossRef]

15. Gilbert, M.T.P.; Tomsho, L.P.; Rendulic, S.; Packard, M.; Drautz, D.I.; Sher, A.; Tikhonov, A.; Dalen, L.; Kuznetsova, T.; Kosintsev, P.; et al. Whole-genome shotgun sequencing of mitochondria from ancient hair shafts. Science 2007, 317, 1927-1930. [CrossRef]

16. Wong, K. Decoding the Mammoth Scientists sequence half the woolly mammoth's genome. Sci. Am. 2009, 300, 26-27.

17. Roca, A.L.; Ishida, Y.; Nikolaidis, N.; Kolokotronis, S.-O.; Fratpietro, S.; Stewardson, K.; Hensley, S.; Tisdale, M.; Boeskorov, G.; Greenwood, A.D. Genetic variation at hair length candidate genes in elephants and the extinct woolly mammoth. BMC Evol. Biol. 2009, 9, 232. [CrossRef] [PubMed]

18. Spilde, M.; Lanzirotti, A.; Qualls, C.; Phillips, G.; Ali, A.M.; Agenbroad, L.; Appenzeller, O. Biologic Rhythms Derived from Siberian Mammoths2019 Hairs. PLoS ONE 2011, 6, e21705. [CrossRef] [PubMed]

19. Bocherens, H. Isotopic tracking of large carnivore palaeoecology in the mammoth steppe. Quat. Sci. Rev. 2015, 117, 42-71. [CrossRef]

20. Ukraintseva, V. Vegetation and Climate of Siberia in the Mammoth Epoch; East Siberian Branch of the International Institute of Forest: Krasnoyarsk, Russia, 2002. (In Russian)

21. Iacumin, P.; Davanzo, S.; Nikolaev, V. Short-term climatic changes recorded by mammoth hair in the Arctic environment. Palaeogeogr. Palaeoclimatol. Palaeoecol. 2005, 218, 317-324. [CrossRef]

22. Bocharova, N.; Treu, G.; Czirjak, G.A.; Krone, O.; Stefanski, V.; Wibbelt, G.; Unnsteinsdottir, E.R.; Hersteinsson, P.; Schares, G.; Doronina, L.; et al. Correlates between Feeding Ecology and Mercury Levels in Historical and Modern Arctic Foxes (Vulpes lagopus). PLoS ONE 2013, 8, e60879. [CrossRef]

23. Vo, A.-T.E.; Bank, M.S.; Shine, J.P.; Edwards, S.V. Temporal increase in organic mercury in an endangered pelagic seabird assessed by century-old museum specimens. Proc. Natl. Acad. Sci. USA 2011, 108, 7466-7471. [CrossRef]

24. Strekopytov, S.; Brownscombe, W.; Lapinee, C.; Sykes, D.; Spratt, J.; Jeffries, T.E.; Jones, C.G. Arsenic and mercury in bird feathers: Identification and quantification of inorganic pesticide residues in natural history collections using multiple analytical and imaging techniques. Microchem. J. 2017, 130, 301-309. [CrossRef]

25. Sun, L.; Yin, X.; Liu, X.; Zhu, R.; Xie, Z.; Wang, Y. A 2000-year record of mercury and ancient civilizations in seal hairs from King George Island, West Antarctica. Sci. Total Environ. 2006, 368, 236-247. [CrossRef]

26. Pozebon, D.; Scheffler, G.L.; Dressler, V.L. Elemental hair analysis: A review of procedures and applications. Anal. Chim. Acta 2017, 992, 1-23. [CrossRef]

27. Popov, A.I. A mammoth from Taymyr and problem of the mammoth fauna remnants in the Siberian Quaternary deposits. In The Ice Age in the European Section of the USSR and in Siberia; Markov, K.K., Popov, A.I., Eds.; MGU: Moscow, Russia, 1956; pp. 259-275.

28. Gavrilova, M.K. Climates of the Cold Regions of the Earth; Siberian Branch of RAS Publishing House: Yakutsk, Russia, 1998. 
29. Vereshchagin, N.K. Berelekh "cemetery" of mammoths. Proc. Zool. Inst. Acad. Sci. USSR 1977, 72, 5-50.

30. Boeskorov, G.G.; Tikhonov, A.N.; Suzuki, N. The Yukagir Mammoth; Saint-Petersburg University Publishing House: Saint-Petersburg, Russia, 2007; p. 252.

31. Boeskorov, G.G.; Tikhonov, A.N.; Lazarev, P.A. A new find of a mammoth calf. Dokl. Biol. Sci. 2007, 417, 480-483. [CrossRef] [PubMed]

32. Grigoriev, S.E.; Fisher, D.C.; Obadă, T.; Shirley, E.A.; Rountrey, A.N.; Savvinov, G.N.; Garmaeva, D.K.; Novgorodov, G.P.; Cheprasov, M.Y.; Vasilev, S.E.; et al. A woolly mammoth (Mammuthus primigenius) carcass from Maly Lyakhovsky Island (New Siberian Islands, Russian Federation). Quat. Int. 2017, 445, 89-103. [CrossRef]

33. Lazarev, P.A.; Boeskorov, G.G.; Tomskaya, A.I.; Garutt, N.V.; Vasilyev, E.M.; Kasparov, A.K. Mammals of the Anthropogen of Yakutia; Publishing House YAC SB RAS: Yakutsk, Russia, 1998.

34. Boeskorov, G.G.; Potapova, O.R.; Protopopov, A.V.; Plotnikov, V.V.; Agenbroad, L.D.; Kirikov, K.S.; Pavlov, I.S.; Shchelchkova, M.V.; Belolyubskii, I.N.; Tomshin, M.D.; et al. The Yukagir Bison: The exterior morphology of a complete frozen mummy of the extinct steppe bison, Bison priscus from the early Holocene of northern Yakutia, Russia. Quat. Int. 2016, 406, 94-110. [CrossRef]

35. Lazarev, P.A. Large Mammals of the Antropogene of Yakutia; Nauka: Novosibirsk, Russia, 2008.

36. Ukraintseva, V.V. Vegetation Cover and Environment of the "Mammoth Epoch" in Siberia; Mammoth Site of Hot Springs: Hot Springs, SD, USA, 1993.

37. Vereshchagin, N.K.; Baryshnikov, G.F. 16-Paleoecology of the mammoth fauna in the Eurasian Arctic. In Paleoecology of Beringia; Hopkins, D.M., Matthews, J.V., Schweger, C.E., Young, S.B., Eds.; Academic Press: Cambridge, MA, USA, 1982; pp. 267-279.

38. Olivier, R.C.D. 18-Ecology and behavior of living elephants: Bases for assumptions concerning the extinct woolly mammoths. In Paleoecology of Beringia; Hopkins, D.M., Matthews, J.V., Schweger, C.E., Young, S.B., Eds.; Academic Press: Cambridge, MA, USA, 1982; pp. 291-305.

39. Morton, J.; Carolan, V.A.; Gardiner, P.H.E. Removal of exogenously bound elements from human hair by various washing procedures and determination by inductively coupled plasma mass spectrometry. Anal. Chim. Acta 2002, 455, 23-34. [CrossRef]

40. Kronstrand, R.; Förstberg-Peterson, S.; Kågedal, B.; Ahlner, J.; Larson, G. Codeine concentration in hair after oral administration is dependent on melanin content. Clin. Chem. 1999, 45, 1485-1494. [CrossRef]

41. Kratzer, K.; Beneš, P.; Spěváčková, V.; Kolihová, D.; Žilková, J. Determination of chemical forms of mercury in human hair by acid leaching and atomic absorption spectrometry. J. Anal. At. Spectrom. 1994, 9, 303-306. [CrossRef]

42. Valereva, E.V.; Ilyina, E.G.; Eyrikh, S.S. Methodical features of sample preparation and determination of mercury (II) in biotic objects. In Proceedings of Young Scientists of Altai State University; ASU: Barnaul, Russia, 2015; pp. 109-111.

43. Eyrikh, S.; Schwikowski, M. Experience of using the atomic fluorescence analyzer "Mercur" for determination ultra-low concentrations of mercury in ice and snow samples. In Mercury. Problems of Geochemistry, Ecology, Analytics; Volosov, A.G., Ed.; IMGRE: Moscow, Russia, 2005; pp. 111-114.

44. WHO/UNEP DTIE Chemical Branch Guidance for Identifying Populations at Risk from Mercury Exposure; WHO: Geneva, Switzerland, 2008.

45. Council, N.R. Toxicological Effects of Methylmercury; The National Academies Press: Washington, DC, USA, 2000; p. 364. [CrossRef]

46. Miroshnikov, S.; Kharlamov, A.; Zavyalov, O.; Frolov, A.; Bolodurina, I.; Arapova, O.; Duskaev, G. Method of Sampling Beef Cattle Hair for Assessment of Elemental Profile. Pak. J. Nutr. 2015, 14, 632-636. [CrossRef]

47. AMAP/UN Environment 2019. Technical Background Report for the Global Mercury Assessment 2018; Arctic Monitoring and Assessment Programme: Oslo, Norway; UN Environment Programme, Chemicals and Health Branch: Geneva, Switzerland, 2019; p. 426.

48. Miroshnikov, S.A.; Zavyalov, O.A.; Frolov, A.N.; Bolodurina, I.P.; Kalashnikov, V.V.; Grabeklis, A.R.; Tinkov, A.A.; Skalny, A.V. The Reference Intervals of Hair Trace Element Content in Hereford Cows and Heifers (Bos taurus). Biol. Trace Elem. Res. 2017, 180, 56-62. [CrossRef]

49. López Alonso, M.; Benedito, J.L.; Miranda, M.; Castillo, C.; Hernández, J.; Shore, R.F. Mercury concentrations in cattle from NW Spain. Sci. Total Environ. 2003, 302, 93-100. [CrossRef] 
50. Sousa, A.C.; Teixeira, I.S.; Marques, B.; Vilhena, H.; Vieira, L.; Soares, A.M.; Nogueira, A.J.; Lillebø, A.I. Mercury, pets' and hair: Baseline survey of a priority environmental pollutant using a noninvasive matrix in man's best friend. Ecotoxicology 2013, 22, 1435-1442. [CrossRef] [PubMed]

51. Lieske, C.L.; Moses, S.K.; Castellini, J.M.; Klejka, J.; Hueffer, K.; O'Hara, T.M. Toxicokinetics of mercury in blood compartments and hair of fish-fed sled dogs. Acta Vet. Scand. 2011, 53, 66. [CrossRef] [PubMed]

52. Laukhin, S.A.; Pushkar, V.S.; Cherepanova, M.V. Modern condition of environmental reconstructions on Siberian North during Karginsky time (Late Pleistocene). Bull. Mosc. Soc. Nat. Geol. Ser. 2012, 87, 37-48.

53. Vlasakker, J.V.D. Bison Rewilding Plan 2014-2024-Rewilding Europe's Contribution to the Comeback of the European Bison; Rewilding Europe: Nijmegen, The Netherlands, 2014.

54. Durkalec, M.; Nawrocka, A.; Krzysiak, M.; Larska, M.; Kmiecik, M.; Posyniak, A. Trace elements in the liver of captive and free-ranging European bison (Bison bonasus L.). Chemosphere 2018, 193, 454-463. [CrossRef]

55. Kośla, T.; Skibniewska, E.; Skibniewski, M. The state of bioelements in the hair of free-ranging European bisons from Bialowieza Primeval Forest. Pol. J. Vet. Sci. 2011, 14, 81-86. [CrossRef]

56. Chatterjee, A.; Raquib, M.; Sheikh, I.U.; Bhattacharya, M. Elemental status in yak hair. Indian Vet. J. 2005, 82, 526-528.

57. Patrashkov, S.A.; Petukhov, V.L.; Korotkevich, O.S.; Petukhov, I.V. Content of heavy metals in the hair. J. Phys. IV Fr. 2003, 107, 1025-1027. [CrossRef]

58. Friedrichs, K.R.; Harr, K.E.; Freeman, K.P.; Szladovits, B.; Walton, R.M.; Barnhart, K.F.; Blanco-Chavez, J. ASVCP reference interval guidelines: Determination of de novo reference intervals in veterinary species and other related topics. Vet. Clin. Pathol. 2012, 41, 441-453. [CrossRef]

59. Egeland, G.M.; Ponce, R.; Bloom, N.S.; Knecht, R.; Loring, S.; Middaugh, J.P. Hair methylmercury levels of mummies of the Aleutian Islands, Alaska. Environ. Res. 2009, 109, 281-286. [CrossRef]

60. Arnold, S.; Parker, J.; Bloom, N.; Aufderheide, A.; Middaugh, J. Mercury in Ancient Mummy Hair from Peru, Chile, and Egypt_Evidence of Pre-Industrial Naturally Occurring Dietary Exposure 22 May 2018. 2018. Available online: http://dhss.alaska.gov/dph/Epi/eph/Documents/biom/Mummy\%20Mercury\%20Study.2018. pdf (accessed on 29 September 2020).

61. Dietz, R.; Outridge, P.M.; Hobson, K.A. Anthropogenic contributions to mercury levels in present-day Arctic animals-A review. Sci. Total Environ. 2009, 407, 6120-6131. [CrossRef]

62. Dunlap, K.L.; Reynolds, A.J.; Bowers, P.M.; Duffy, L.K. Hair analysis in sled dogs (Canis lupus familiaris) illustrates a linkage of mercury exposure along the Yukon River with human subsistence food systems. Sci. Total Environ. 2007, 385, 80-85. [CrossRef] [PubMed]

63. Gustin, M.S.; Bank, M.S.; Bishop, K.; Bowman, K.; Branfireun, B.; Chételat, J.; Eckley, C.S.; Hammerschmidt, C.R.; Lamborg, C.; Lyman, S.; et al. Mercury biogeochemical cycling: A synthesis of recent scientific advances. Sci. Total Environ. 2020, 737, 139619. [CrossRef] [PubMed]

64. Cooke, C.A.; Martinez-Cortizas, A.; Bindler, R.; Gustin, M.S. Environmental archives of atmospheric $\mathrm{Hg}$ deposition-A review. Sci. Total Environ. 2020, 709. [CrossRef] [PubMed]

65. Smulsky, J. New results on the earth insolation and their correlation with the late pleistocene paleoclimate of West Siberia. Geol. Geophys. 2016, 57, 1393-1407. [CrossRef]

66. Schuster, P.F.; Schaefer, K.M.; Aiken, G.R.; Antweiler, R.C.; Dewild, J.F.; Gryziec, J.D.; Gusmeroli, A.; Hugelius, G.; Jafarov, E.; Krabbenhoft, D.P.; et al. Permafrost Stores a Globally Significant Amount of Mercury. Geophys. Res. Lett. 2018, 45, 1463-1471. [CrossRef]

67. Jitaru, P.; Gabrielli, P.; Marteel, A.; Plane, J.M.C.; Planchon, F.A.M.; Gauchard, P.-A.; Ferrari, C.P.; Boutron, C.F.; Adams, F.C.; Hong, S.; et al. Atmospheric depletion of mercury over Antarctica during glacial periods. Nat. Geosci. 2009, 2, 505-508. [CrossRef]

68. Lambert, F.; Delmonte, B.; Petit, J.R.; Bigler, M.; Kaufmann, P.R.; Hutterli, M.A.; Stocker, T.F.; Ruth, U.; Steffensen, J.P.; Maggi, V. Dust-climate couplings over the past 800,000 years from the EPICA Dome C ice core. Nature 2008, 452, 616-619. [CrossRef]

69. Ruth, U.; Bigler, M.; Röthlisberger, R.; Siggaard-Andersen, M.-L.; Kipfstuhl, S.; Goto-Azuma, K.; Hansson, M.E.; Johnsen, S.J.; Lu, H.; Steffensen, J.P. Ice core evidence for a very tight link between North Atlantic and east Asian glacial climate. Geophys. Res. Lett. 2007, 34. [CrossRef] 
70. Waelbroeck, C.; Lougheed, B.C.; Riveiros, N.V.; Missiaen, L.; Pedro, J.; Dokken, T.; Hajdas, I.; Wacker, L.; Abbott, P.; Dumoulin, J.-P.; et al. Consistently dated Atlantic sediment cores over the last 40 thousand years. Sci. Data 2019, 6. [CrossRef]

71. Kirillova, I.V.; Argant, J.; Lapteva, E.G.; Korona, O.M.; van der Plicht, J.; Zinovyev, E.V.; Kotov, A.A.; Chernova, O.F.; Fadeeva, E.O.; Baturina, O.A.; et al. The diet and environment of mammoths in North-East Russia reconstructed from the contents of their feces. Quat. Int. 2016, 406, 147-161. [CrossRef]

Publisher's Note: MDPI stays neutral with regard to jurisdictional claims in published maps and institutional affiliations.

(C) 2020 by the authors. Licensee MDPI, Basel, Switzerland. This article is an open access article distributed under the terms and conditions of the Creative Commons Attribution (CC BY) license (http://creativecommons.org/licenses/by/4.0/). 